原著

\title{
破裂脳動脈瘤クリッピングの工夫
}

ークリッピングしやすい動脈瘤を作り出す一

乾 登史孝, 奥野 修三

\section{Surgical Techniques of Clipping for Ruptured Cerebral
Aneurysms: Aneurysmoplasty for an Ideal Clipping of Large- \\ Surgical Techniques of Clipping for Ruptured Cerebral
Aneurysms: Aneurysmoplasty for an Ideal Clipping of Large- sized Ruptured Cerebral Aneurysms}

\author{
Toshitaka InUI, M.D. and Shuzo OKunO, M.D. \\ Department of Neurosurgery, Bell-land General Hospital, Sakai, Osaka, Japan
}

\begin{abstract}
Summary: The treatment of relatively large cerebral aneurysms by direct clipping has been reported to significantly increase operative morbidity. In this article, we introduce a newly conducted surgical technique of aneurysmoplasty, which is most suitable for clipping of these ruptured aneurysms and implies additional methods to prevent surgical injury to surrounding vessels and brain tissues. The main concept of aneurysmoplasty includes tentative clipping in the early stage of aneurysm dissection and reduction in size of aneurysms by low output bipolarcoagulation. These methods are systemically arranged and titrated according to the aneurysm's size and location.

Transforming large ruptured aneurysms to small unruptured aneurysms apparently improves safety and reliability in clipping procedure by direct inspection around the neck and behind the dome of aneurysms.
\end{abstract}

\author{
Key words: \\ - aneurysmoplasty \\ - de novo unruptured \\ aneurysm \\ - tentative clip \\ - bipolar coagulation \\ technique
}

Surg Cereb Stroke

(Jpn) 39: 420-425, 2011

\section{はじめに}

破裂脳動脈瘤の治療においては, International Subarachnoid Aneurysm Trial (ISAT)に代表される近年の大 規模臨床試験の結果を考慮すると, 現状でそれらに対する クリッピング術の選択に以前のような優位性を見出しにく くなった ${ }^{1011)}$. ただし, 各調查や試験にはさまざまな指摘 や反論もあり, 一様に血管内治療との優劣を論ずることは 時期尚早と思われる，たとえば動脈瘤治癒率において，ク リッピング術がコイル塞栓術に比べて優れていることは明
白であり, 各治療法はその特徴としての長所と短所を内包 しており，その点を熟知したうえで症例ごとに治療適応を 検討すべきである ${ }^{14)}$.

脳動脈㖃クリッピング術の合併症発生を考えるとき, 動 脈瘤の大きさが重要な因子であることは明らかである212). これまで, われわれは比較的大きいサイズの破裂動脈瘤に 対するクリッピング術では, 勇気や胆力によらず, 具体的 な手順を段階的に踏襲することで, 破裂動脈瘤を未破裂化 かつ縮小化させ, その可動性を得ることで安全で確実な手 技(以下 aneurysmoplasty)を実践してきた。

ベルランド総合病院 脳神経外科(受稿日 2011.3.4)(脱稿日 2011.6.3)〔連絡先： ₹599-8247 大阪府堺市中区東山 500-3 ベルランド総 合病院 脳神経外科 乾 登史孝] [Address correspondence: Toshitaka INUI, M.D., Department of Neurosurgery, Bell-land General Hospital, 500-3 Higashiyama, Naka-ku, Sakai, Osaka 599-8247, Japan] 
Table 1 Summary of the patients who were administrated aneurysmoplasty

\begin{tabular}{ccccccc}
\hline Case & Location & Grade & Initial size & Clipping size & Ratio & GOS \\
\hline 1 & MCA & 2 & 13 & 4 & 0.31 & 5 \\
2 & MCA & 2 & 9 & 5 & 0.56 & 5 \\
3 & IC & 3 & 15 & 5 & 0.33 & 2 \\
4 & MCA & 3 & 11 & 7 & 0.64 & 5 \\
5 & DACA & 2 & 8 & 4 & 0.5 & 5 \\
6 & DACA & 3 & 6 & 4 & 0.67 & 4 \\
7 & DACA & 2 & 7 & 5 & 0.71 & 4 \\
8 & Acom & 1 & 6 & 4 & 0.67 & 5 \\
9 & MCA & 3 & 6 & 3 & 0.5 & 5 \\
10 & MCA & 2 & 14 & 5 & 0.36 & 5 \\
11 & IC & 3 & 9 & 4 & 0.44 & 4 \\
12 & Acom & 4 & 7 & 3 & 0.43 & 3 \\
13 & IC & 3 & 9 & 3 & 0.33 & 4 \\
14 & MCA & 4 & 9 & 4 & 0.44 & 2 \\
15 & Acom & 2 & 7 & 2 & 0.28 & 5 \\
\hline average & & 9.07 & 4.13 & 0.48 &
\end{tabular}

Initial size: aneurysm size before aneurysmoplasty, Clipping size: aneurysm size just before final clipping, Acom: anterior communicating artery aneurysm, DACA: distal anterior cerebral artery aneurysm, IC: internal carotid artery aneurysm, MCA: middle cerebral artery aneurysm, GOS: Glasgow Outcome Scale

本稿では, こうしたクリッピング術の工夫について代表 症例を呈示して詳述し，同時に今後のクリッピング術の治 療成績向上の一助としたい.

\section{対象および方法}

2006 年 6 月から 2009 年 5 月までに当院にてクリッピン グ術を施行した前方循環に発生した動脈瘤 64 例のうち破 裂動脈瘤 32 例を対象とした。部位としては前交通動脈瘤 10 例, 中大脳動脈瘤 9 例, 内頚動脈瘤 9 例, 遠位部前大 脳動脈瘤 4 例であった. そのうち以下に述べる方法で aneurysmoplasty を施行した症例は 15 例であった，原則 的にはまず親血管確保が動脈瘤剝離操作に先立つ．破裂点 と想定される部位に緊張がかからないように動脈瘤䅡部周 辺の剝離を施行する。破裂点を避けてある程度動脈瘤体部 を露出したのち，親血管に temporary clip を置き動脈瘤 内圧を低下させた状態で頚部や体部の壁の薄い部分以外の 体部赤道面からその末梢の壁を低出力 bipolar coagulation により焼灼する。この際使用する bipolar systemは Codman 社製の Malis bipolar coagulator で出力は㧍およ そ20-25 unitsである。この操作を繰り返すことで動脈瘤 体積は有意に縮小し, tentative clipの挿入が可能となる. この時点で破裂動脈瘤は未破裂化したこととなり破裂点も premature rupture を起こすことなく安全に剝離できる. さらに bipolar coagulationにて動脈瘤縮小を進め, より 小さな miniclip で出血点をピンポイントで摘むように掛け
れば, 先ほどの tentative clip は当然不要となり, その除 去でより広い視野を得ることが可能となる．以上の操作に より動脈瘤は全周性に瘉着から解放され可動性を獲得する ことで, 動脈瘤背部の視野も確保され安全確実なクリッピ ングが可能となる(Fig. 5). aneurysmoplasty 前の動脈瘤 サイズの計測は術前の脳血管撮影を基に行った。また aneurysmoplasty 後の動脈瘤サイズは術中の直接計測を使 用した。

\section{結果}

aneurysmoplasty を施行した症例は 15 例， 46.9\% で男 性 5 例, 女性 10 例, 平均年齢 61.8 歳 (41-77 歳)であった。 部位別では前交通動脈瘤 3 例, 中大脳動脈瘤 6 例, 内澒動 脈瘤 3 例，遠位部前大脳動脈瘤 3 例であった. aneurysmoplaty 施行前のサイズ (initial size) は平均 $9.07 \mathrm{~mm}$ (6$15 \mathrm{~mm}$ ), aneurysmoplasty 施行後, 最終的なクリッピン グ直前のサイズ (clipping size) は平均 $4.13 \mathrm{~mm}(2-7 \mathrm{~mm})$ で平均動脈瘤縮小率 (ratio) は $47.8 \%$ であった(Table 1). またクリッピング術に際して premature ruptureをきた した症例は 15 例中 1 例のみであった．全例で術後血管撮 影による動脈藘の完全な消失が確認された。

\section{代表症例提示}

〈症例 1〉66 歳女性.

突然の激しい後頭部痛に引き続く傾眠のため当院に搬送 


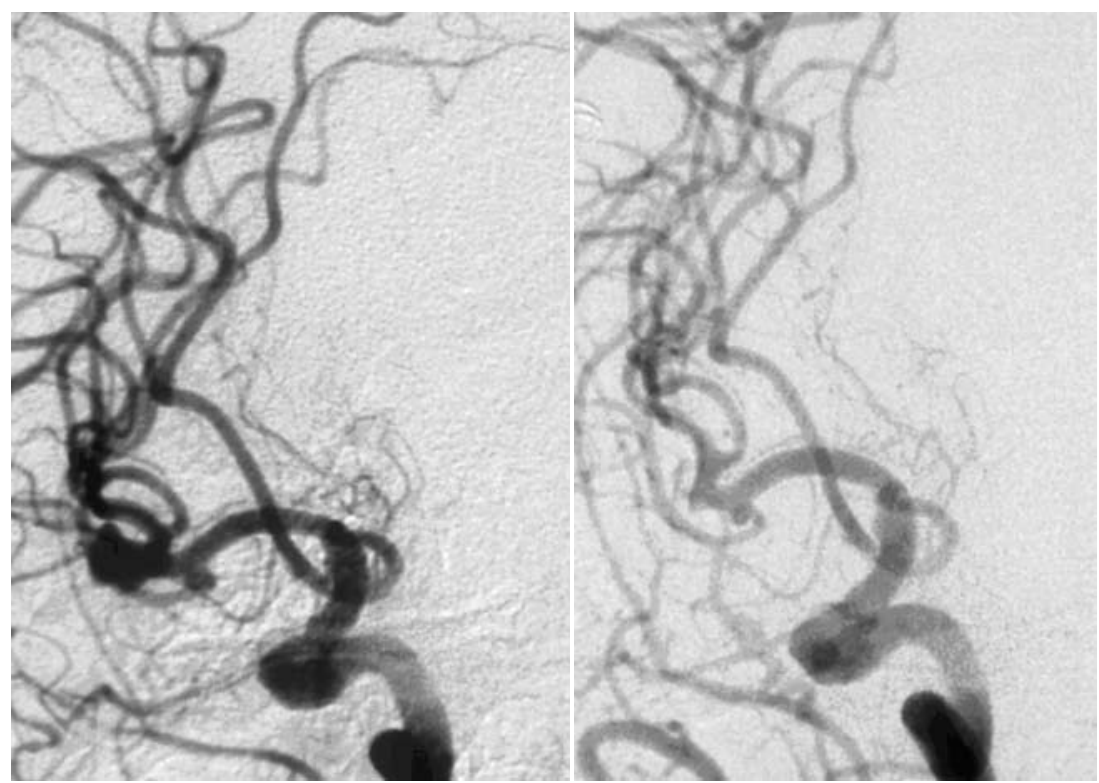

Fig. 1 A: Pre-operative right oblique carotid angiography demonstrating a right middle cerebral artery aneurysm.

B: Post-operative right oblique carotid angiography showing complete

$\mathbf{A} \mid \mathbf{B}$ clipping.

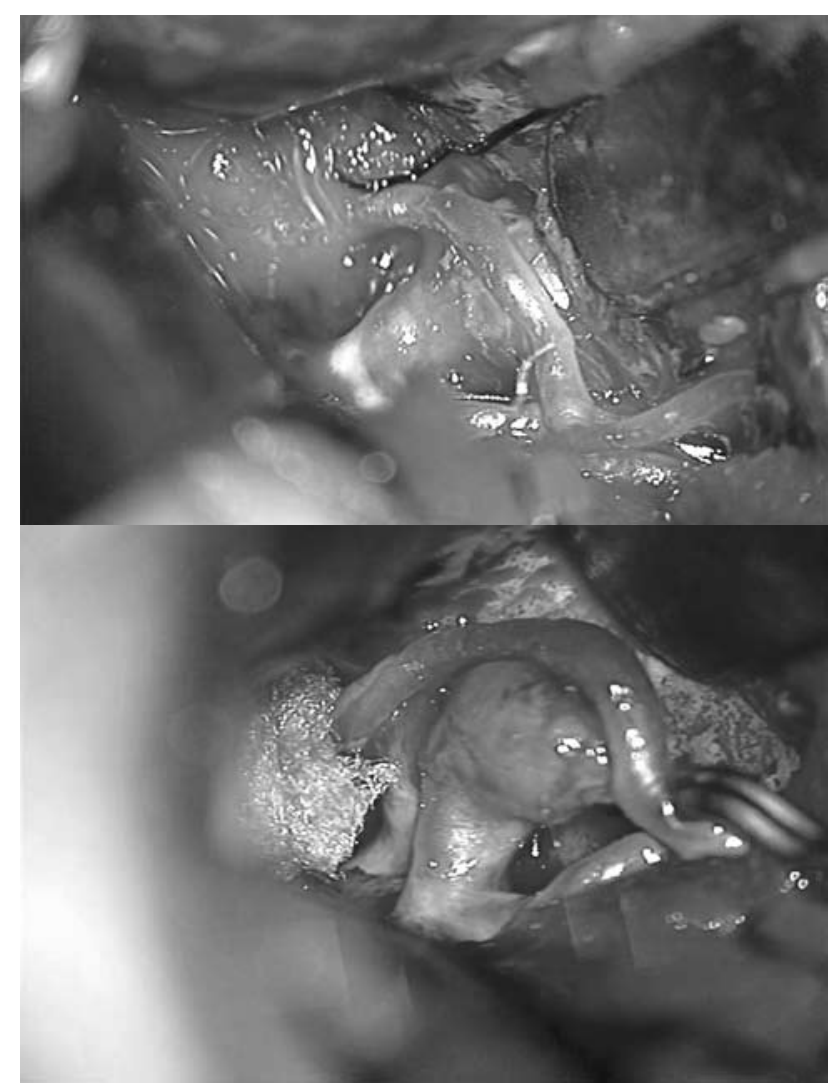

Fig. 2 A: Intra-operative photograph demonstrating an initial aneurysmal condition.

A B: Intra-operative photograph showing an aneu$\overline{\text { B }} \quad$ rysmal condition after clipping for ruptured point with mini clip.
された. 頭部 CTで右シルビウス裂を中心に Fisher group 3 のくも膜下出血を認めた. 脳血管撮影にて右中大 脳動脈分岐部に最大径 $12 \mathrm{~mm}$ の動脈瘤を認めた(Fig. 1). 右前頭側頭開頭を行ったのち, やや遠位側からシルビウス 裂を開放すると動脈瘤の大部分が側頭葉内に埋没してい た。まず親血管である中大脳動脈を確保したのち, premature ruptureに備えて動脈瘤䅡部付近で tentative clip を挿入できるスペースを確保した．動脈瘤を覆う軟化した 脳組織を少量吸引しながら剥離操作をすすめたが, 破裂部 位では周囲組織と強い癒着が認められたため, その直前で 剥離をいったん中断した。ここで動脈瘤䅡部を避け壁の厚 いドーム体部を中心に低出力 bipolar で coagulationする ことで動脈瘤の体積は有意に縮小したため, 破裂部位に到 達することなく容易にドームに tentative clip を行うこと が可能となった。こうして未破裂動脈瘤を作成したのち, 破裂部位は安全に側頭葉内から掘り起こすことが可能とな り，さらに破裂部を摘むように小さなサイズのクリップに 交換することで周辺の視野がより良好となった(Fig. 2). 最終的に破裂動脈瘤は未破裂化, 縮小化され周囲組織との 癒着を完全に剥離することで可動性を得ることができた. その結果多方向からの動脈瘤澒部の観察が容易となり安全 確実にクリッピングを施行した。術後経過は良好で，血管 撮影で動脈瘤は完全に閉塞していた (Fig. 1).

〈症例 2〉77 歳女性.

突然の意識障害にて発症し, 他院からくも膜下出血の診 


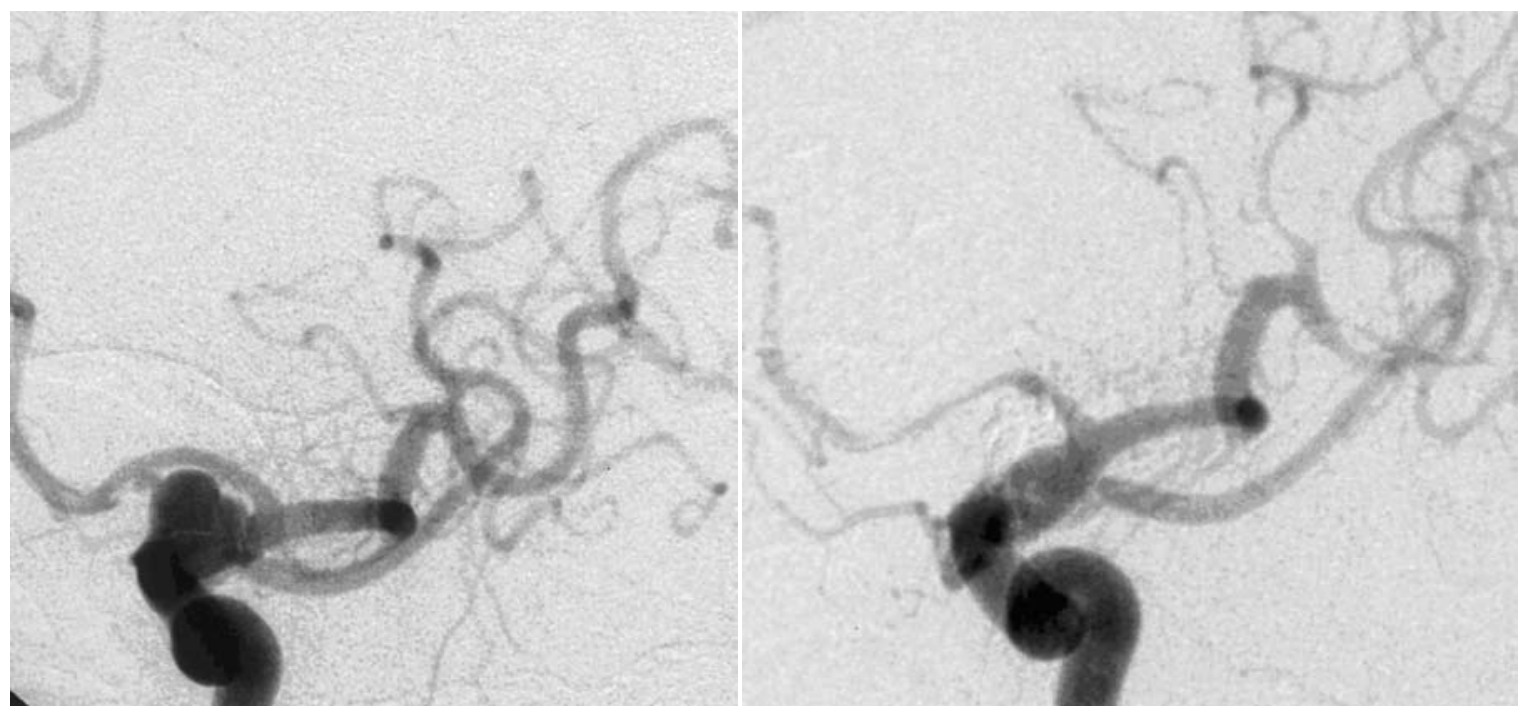

Fig. 3 A: Pre-operative left oblique carotid angiography demonstrating a left internal carotid artery dorsal aneurysm.

B: Post-operative left oblique carotid angiography showing complete clipping.

断にて当院に紹介搬送された．頭部 CT にて両側シルビウ 又裂を中心とする Fisher group 4 のくも膜下出血を認め た．脳血管撮影では左内䅡動脈 C2 背側に broad base で 先端に blebを伴う最大径 $15 \mathrm{~mm}$ の動脈瘤を認めた(Fig. 3）。また用手的 Matas testにて前交通動脈を介して左内 䅡動脈環流域への十分な側副血流を認めた. 同日, 左前頭 側頭開頭を行うと同時に䅡部で左内頝動脈を確保した。内 頚動脈トラッピングの可能性があるため, 動脈瘤到達に先 立ち浅側頭動脈・中大脳動脈吻合術を施行した。引き続 き，シルビウス裂を末梢側から十分に開放して中大脳動脈 を中枢側にたどると，動脈瘤は内頚動脈 $\mathrm{C} 2$ 部の上内側壁 に広く neckを有しており，その dome は赤々と䐍隆し壁 の薄いことが予想された。 また dome 壁は前大脳動脈 A1 部に広くかつ強固に癒着しており，その先端部の bleb は 視神経の直下に埋没しているようであった。単純に neck のみを剝離してクリッピング操作を行えば neck 近傍の動 脈瘤壁に過大な力が加わり，おそらくは裂けてしまう可能 性が高いと思われた。まず頚部内頝動脈を断続的にクラン プしながら dome 内圧を下げ低出力の bipolar coagulation を用いて dome の赤道面より末梢側を焼灼しながら動脈瘤 サイズを減じていった，途中， bleb から出血を認めたが 即座に clip にて閉塞することで未破裂化することができ た。この時点で動脈瘤内圧は依然高く dome と A 1 との剥 離は非常に困難であったため, suction decompression technique を用いて，さらに内圧を下げることで比較的容 易に両者の分離操作をなしえだ)。さらに bipolar coagu-
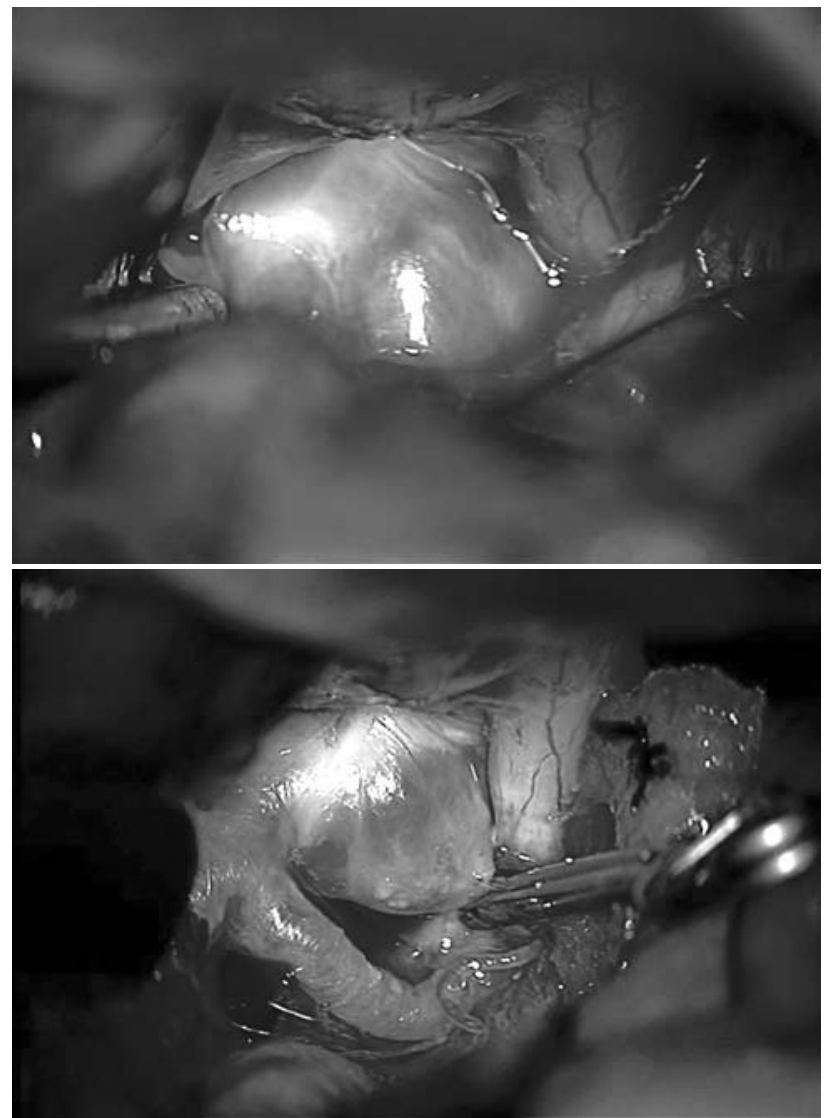

Fig. 4 A: Intra-operative photograph showing an initial aneurysmal condition.

A B: Intra-operative photograph demonstrating an

B aneurysmal condition after aneurysmoplasty.

Surgery for Cerebral Stroke 39: 2011 

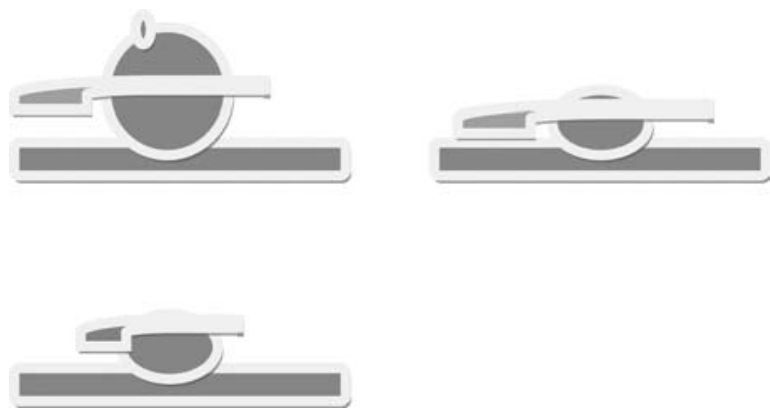

Fig. 5 Schematic representation of making 'de novo unruptured aneurysm.'

A: Tentative dome clip is applied proximal to the ruptured point.

A B B: Under proximal control with temporary clip etc, bipolar coagulation technique is used for shrinkage of the aneurysm.

C: Mini-clip is applied at the shrunken point of distal to dome clip, and then dome clip is then, neck clipping is performed by permanent clip.

lation によって動脈瘤壁を退縮させていき, 最終的には完 全に周囲との癒着のない縮小した未破裂動脈瘤に変更する ことができ，安全にクリッピングすることができた(Fig. 4). 術後血管撮影にて動脈瘤の完全消失を確認したが (Fig. 3), 術後脳血管攣縮にて多発性脳梗塞が出現し, 要 介助の状態で転院となった。

\section{考察}

脳動脈㾿クリッピング術の最大の目的は, 穿通枝梗塞を 始めとする虚血性合併症を回避して動脈瘤からの出血を防 止することであるが，サイズが大きくなれば，動脈㢚壁と 周囲の重要な神経・血管組織との癒着は必至であり, これ らをいかに安全・確実に剥離するかが重要課題となる. 事 実, 動脈瘤のサイズに比例して治療が困難となり, 合併症 発生率が上昇することは過去の報告および日常の臨床経験 からもよく知られている ${ }^{27)}$. これまでにも, クリッピン グ術に関するさまざまな工夫が報告されてきたが4)58(9)131), 比較的サイズの大きな破裂脳動脈瘤の剶離開始時点からク リッピング操作に至る経過を段階的な手順としてとらえ, その具体的な目的を考察した報告は少ない。

われわれが実践してきた工夫の目的は, 直視下に安全で 確実なクリッピング術を実施すること, 言い換えれば動脈 瘤を破裂させずに縮小化し，さらに周囲組織から完全に剝 離することで可動性を得ることになる。この手順を行うに 先だって, シルビウス裂を必要かつ十分に開放し，できる だけ早期に親血管を確保することは，これまでと同様であ る。また, 動脈瘤の頚部が容易に剝離され, 周囲組織の癒 着もないのであれば, そのままクリッピング操作に移行す
ればよい. 今回の対象症例の動脈瘤サイズの平均は 9.07 $\mathrm{mm}$ であり, 全例で血管分枝(穿通枝を含む)や周囲の神経 組織との癒着が認められた。普段から「早くクリップを掛 けたい」ではなく癒着を解除し「安全, 確実にクリップを 掛けたい」という心構えを持つことは重要と思われる。破 裂動脈瘤に対するクリッピング術では少なからず破裂に対 する恐怖心や血性術野による視認性の低下によるストレス から手術手順の見極めが不十分になりやすい. その結果, 手順を踏まずに動脈瘤の一部を確認すると, 頚部の剩離の みを行い即座にクリッピング操作に移行しがちである。と ころが剝離操作や確認作業が不十分であると動脈瘤澒部周 囲に余計な力が加わり裂けてしまったり，穿通枝などの重 要構造物を損傷するなどの合併症が生じうる. ある期間, ある部分を確認していないわけであるから，ある一定の確 率で後遺症が発生するのは当然である.

われわれが呈示する破裂脳動脈瘤クリッピング術の工夫 における最大要件は破裂に対する危惧を低減することにあ る.未破裂化した動脈瘤の剥離であれば精神的に余裕が得 られ，マイクロ下の手技に集中できるからである.さらに, premature rupture はクリッピング術の合併症発生率を増

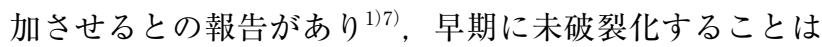
きわめて重要である，実際の手術では, 動脈瘤の姿が少し でも見え始めたなら，常に未破裂化する手順を念頭に置か なければならない。もちろん, 術前から画像所見を十分に 検討し, 術野を構想して未破裂化に必要な手順を把握して おかねばならない. 動脈瘤に接近して術野に出血部位から 見えることはまずないのであるから，最初にドームのどの 部位に tentative clip が抻入できるのか判断する必要があ る. 周囲の構造物を考慮して安全な剝離部位やクリップの 挿入方向およびその深度を予測する．時に動脈瘤が大きく 緊満なために tentative clip 挿入が困難な場合もあるが, 方法で先述した順序で dome coagulationを使用ながら tentative clip で破裂動脈瘤を未破裂化することが可能で ある.もちろん bipolar coagulation には, 症例 2 でも経 験したように premature rupture の危険性はあるがこの 方法での破裂は，すでに親血管を確保しある程度動脈瘤䅡 部を確認したのちの事象であるため premature rupture した部位に proximal control しながら tentative clip を置 くことは容易である。このように縮小した未破裂動脈瘤の 背部をさらに注意媣く剥離することで, 全周性に癒着から 解放され，動脈瘤の可動性が獲得される．すなわち多方向 からの動脈瘤䅡部の観察が容易となりクリッピング操作の 安全性，確実性が向上することとなる.

\section{結語}

われわれは，比較的サイズの大きな破裂脳動脈瘤手術に 
おいて，安全で確実なクリッピングを施行するため aneurysmoplasty を実践してきた．この方法は bipolar coagulationによる動脈瘤の縮小化および, tentative clipによ る未破裂化により動脈瘤に可動性を持たせることを可能と し，動脈瘤䅡部に対する多方面的な視野確保を容易にする ものである. 結果として安全確実なクリッピングを実現で きる.

\section{文献}

1) Batjer H, Samson D: Intraoperative aneurysmal rupture: Incidence, outcome, and suggestions for surgical management. Neurosurgery 18: 701-707, 1986

2) Cantore G, Santoro A, Guidetti G, et al: Surgical treatment of giant intracranial aneurysms: Current viewpoint. Neurosurgery 63(suppl 2): 279-289, 2008

3）伊達 勲, 徳永浩司: Suction decompression 法を併用した 巨大・大型 paraclinoid 動脈瘤のクリッピング術一そのセッ ティングとクリッピング時の留意点. 脳神経外科 37 (2): 135-146, 2009

4）藤岡正導, 西 徹：血管閉塞を防ぐための “tentative parallel clipping method”。脳神経外科速報 15: 24-27, 2005

5）波出石 弘, 鈴木明文, 師井淳太 : 脳動脈瘤手術の工夫. 脳卒中の外科 34: 340-346, 2006

6) Higashida RT, Lahue BJ, Torbey MT, et al: Treatment of unruptured intracranial aneurysms: a nationwide assessment of effectiveness. AJNR Am J Neuroradiol 28: 146-151, 2007

7) Houkin K, Kuroda S, Takahashi A, et al: Intra-operative premature rupture of the cerebral aneurysms. Analysis of the cause and management. Acta Neurochir (Wien) 141: 1255-1263, 1999

8）岩間 亨, 吉村紳一, 安藤弘道, ほか：安全, 確実な脳動 脈瘤手術の手順と工夫一動脈瘤手術の最終段階における dome puncture の役割一. 脳卒中の外科 35: 411-416, 2007

9）岩間 亨, 坂井 昇：脳動脈瘤手術に打ける dome puncture の重要性一特に前交通動脈瘤手術における穿通枝温存 のために一。脳卒中の外科 30: 375-379, 2002

10) Molyneux AJ, Kerr RSC, Yu LM, et al: Risk of recurrent subarachnoid hemorrhage, death, or dependence and standardized mortality ratios after clipping or coiling of an intracranial aneurysm in the international subarachnoid aneurysm trial (ISAT): long-term followup. Lancet Neurol 8 (5): 427-433, 2009

11) Molyneux AJ, Kerr RSC, Yu LM, et al: International subarachnoid aneurysm trial (ISAT) of neurosurgical clipping versus endovascular coiling in 2143 patients with ruptured intracranial aneurysms: a randomized comparison of effects on survival, dependency, seizures, rebleeding, subgroups and aneurysm occlusion. Lancet 366: 809-817, 2005

12) Nakase H, Shin Y, Kanemoto $Y$, et al: Long-term outcome of unruptured giant cerebral aneurysms. Neurol Med Chir (Tokyo) 46: 379-386, 2006

13）西 徹, 古賀一成, 山城重雄, ほか: 安全かつ有効な脳動 脈瘤䅡部クリッピングのための技術と工夫. 脳卒中の外科 35: 83-88, 2007

14）塩川芳昭, 栗田浩樹, 藤井清孝, ほか：急性期破裂脳動脈 瘤の治療選択の現状(第一報) 一 2005 年前向き集計一. 脳卒 中の外科 37: 1-6, 2009 